\section{Pengaruh Biaya Kontrulksi Rumah Sederhana Murah Pada Industri Perumahan Terhadap Daya Beli Masyarakat Berpenghasilan Rendah}

\section{Karel Soekma Jaya}

Pengembang Perumahan PT Cipta Griya Sarana Asri, Balikpapan

\section{karelsja@yahoo.co.id}

Dalam industri perumahan harga atau biaya kontruksi rumah sangat menentukan harga jual, karena hampir separuh komponen biaya perumahan disumbang oleh biaya kontruksi rumah. Hal ini juga berimbas pada kemampuan daya beli masyarakat berpenghasilan rendah (MBR). Paper ini focus membahas sejauh mana pengaruh biaya kontruksi rumah sederhana murah pada Industri perumahan terhadap daya beli MBR. Untuk mengukur pengaruh tersebut, digunakan analisis perbandingan biaya rumah sederhana murah dengan data standar harga rumah murah menggunakan ketentuan yang telah diatur oleh pemerintah. Empat sampel digunakan dalam menentukan prosentase biaya kontruksi rumah serta melakukan simulasi biaya kontruksi rumah sederhana murah tipe 36 berdasarkan Analisa harga satuan pekerjaan (AHSP) tahun 2018. Hasil analisis ini menunjukkan bahwa model rumah, pemilihan material, dan perubahan jenis pekerjaan sangat menentukan biaya kontruksi rumah, sehingga mempengaruhi daya beli MBR.

Kata kunci: MBR, AHSP, rumah sederhana, daya beli

Diajukan: 31 Mei 2020

Direvisi: 28 Juli 2020

Diterima: 17 September 2020

Dipublikasikan online: 18 September 2020

masyarakat berpenghasilan rendah dan mengurangi tingginya tingkat kebutuhan perumahan di Indonesia.

Pemerintah telah membuat kebijakan yang lebih berpihak kepada kepada MBR dengan mengatur uang muka $1 \%$, bebas biaya PPN, bebas premi asuransi, suku bunga 5\% dan jangka waktu kredit hingga 20 tahun. Melalui kebijakan tersebut Pemerintah secara optimis menetapkan target untuk menekan tingkat kebutuhan rumah (backlog), perumahan, yaitu dari sebesar 11,4 juta unit pada 2015 menjadi 7,6 juta unit pada 2019 (Nabila, 2019).

Namun optimisme dan kebijakan pemerintah itu, tidak secara otomatis dapat menghambat laju kenaikan harga perumahan, yang setiap tahunnya mengalami kenaikan akibat inflasi, harga tanah, harga BBM, harga sewa alat berat, harga material, dan upah kerja. Sementara dilain pihak daya beli MBR semakin berkurang.

Terdapat 3 faktor yang mempengaruhi harga perumahan bagi MBR, yaitu faktor perizinan, faktor lahan, faktor prasarana, sarana dan utilitas (PSU) dan faktor kontruksi rumah. Kontruksi rumah yang dimaksud disini adalah kontruksi Rumah Sederhana Murah (RSM).

Yang dimaksud dengan rumah sederhana murah adalah rumah yang dibangun oleh pengembang perumahan dengan mengikuti ketentuan yang telah diatur oleh Pemerintah, yang diperuntukkan untuk memenuhi kebutuhan MBR, yang pembeliannya memanfaatkan fasilitas kredit pemilikan rumah subsidi

Cara mensitasi artikel ini:

Jaya, K.S (2020) Pengaruh Biaya Kontruksi Rumah Sederhana Murah Pada Industri Perumahan Terhadap Daya Beli Masyarakat Berpenghasilan Rendah Buletin Profesi Insinyur 3(2) 070-076 
(FLPP) pada bank yang telah ditunjuk oleh pemerintah. Harga jual rumahnya harus sesuai dengan harga jual yang ditetapkan oleh Pemerintah, dan yang menerima fasilitasnya adalah MBR-nya yang bergaji atau berpenghasilan sesuai dengan skema yang telah ditetapkan oleh Pemerintah.

Adapun pengembang perumahan yang membangun rumah sederhana murah sesuai dengan ketentuan yang telah diatur pemerintah akan memperoleh bantuan stimulan PSU, yang mana bantuan stimulan PSU tersebut dimaksudkan agar pengembang perumahan tidak membebani lagi biaya PSU pada harga jual rumah sederhana murah guna menekan harga jual.

Kontruksi dari rumah sederhana murah tidak diatur, kecuali utuk harga jual dan luas bangunan harus 36 meter persegi, sehingga kontruksi dari rumah sederhana murah dapat dikembangkan dan direkayasa baik model, denah, struktur maupun material yang digunakan dengan memanfaatkan material pabrikasi dan kearifan lokal.

Selanjut untuk alasan penyederhanaan di sini penulis hanya membahas faktor rumah saja. Sementara faktor-faktor lainnya ditentukan berdasarkan prosentase biaya dari masing-masing faktor tersebut terhadap harga jual.

\section{Metode}

Untuk mengetahui seberapa besar pengaruh biaya kontruksi RSM terhadap daya beli MBR, maka dilakukan analisis perbandingan. Dalam analisis ini penulis memanfaatkan fasilitas dari software microsoft exel 2016. Yang mana daya beli MBR dinotasikan dengan $Y$ dan biaya kontruksi dinotasikan $X$.

Selanjutnya untuk kebutuhan analisis, penulis mengumpulkan data dari Surat Keputusan Menteri PUPR untuk memperoleh standar penghasilan maksimal yang dapat diberikan fasilitas Kredit Pemilikan Rumah FLPP, Peraturan Pemerintah (PP) tentang gaji ASN, TNI dan Polri untuk mengetahui besar gaji yang masuk dalam skim kredit pemilikan rumah FLPP dan Surat Keputusan Gubernur Kalimantan Timur tentang Upah Minimum Provinsi dan Kabuaten/Kota untuk mengetahui besar penghasilan yang masuk dalam skim kredit pemilikan rumah FLPP. Yang mana data tersebut dipergunakan untuk mengukur daya beli MBR.

Sementara untuk mengetahui dan menghitung biaya kontruksi RSM dari harga jual RSM, maka penulis melakukan sampling terhadap empat perumahan kemudian menghitung nilai rata-rata dari masingmasing faktor yang mempengaruhi harga jual RSM. Selanjutnya nilai tersebut dianalisis. Sehingga dapat diketahui nilai atau biaya dari kontruksi RSM. Data ini, selanjutnya, disimulasikan terhadap pemilihan material dan kontruksi yang akan digunakan pada RSM tersebut.

Dalam kasus ini digunakan data tahun 2018, karena Surat Keputusan Menteri PUPR, baru berlaku pada Juli 2019.
Kemudian untuk mengetahui biaya kontruksi RSM, maka dihitung RAB RSM dari ke empat sampel yang digunakan pada penilitian ini berikut pemilihan material dan kontruksi dari masing-masing sampel RSM tersebut.

Dalam hal ini penulis menggunakan Analisa Harga Satuan Pekerjaan (AHSP) dari Dinas Pekerjaan Umum (PU) Kota Balikpapan tahun 2018. Dalam hal ini, luas lantai dari RSM tersebut adalah 36 meter persegi.

Adapun tahap-tahap metodologi analisis yang dipergunakan dapat dilihat pada Gambar 1.

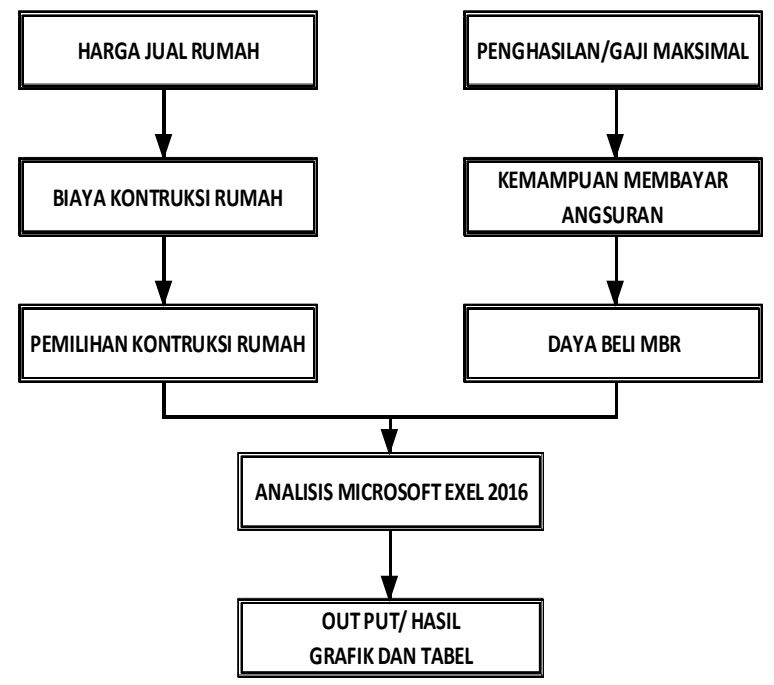

Gambar 1 Flowchart metodologi

\section{Analisis}

\section{Harga Jual Rumah}

Harga jual Rumah adalah harga yang ditentukan oleh pengembang perumahan untuk 1 unit rumah di komplek perumahan beserta fasilitasnya yang dibangun dan dijual oleh pengembang perumahan kepada masyarakat. Umumnya dalam industri perumahan harga jual terdiri dari biaya produksi, biaya tidak langsung serta jasa.

Dalam kasus RSM, harga jual maksimum telah ditentukan oleh pemerintah dalam hal ini Kementerian PUPR yang sebelumnya adalah Kementerian Perumahan Rakyat.

Sementara pengembang perumahan yang berkeinginan membangunan perumahan rumah sederhana murah bagi MBR dan memanfaatkan segala fasilitas stimulan program FLPP wajib mengikuti ketentuan tersebut, yaitu dengan menetapkan harga jual setinggi-tingginya sesuai dengan harga maksimal yang telah ditetapkan oleh pemerintah.

Khusus harga jual rumah sederhana murah yang diperuntuk bagi MBR, Pemerintah dalam hal ini kementerian PUPR pada setiap tahunnya menetapkan harga jual maksimal dari rumah sederhana murah dalam suatu Surat Keputusan Menteri PUPR. 
Adapun harga jual rumah sederhana murah tahun 2019 tercantum di dalam Surat Keputusan Menteri PUPR Nomor 535/KPTS/M/2019 dan tahun 2018 tercantum di dalam Surat Keputusan Menteri PUPR Nomor 1126/KPTS/M/2018 dan Peraturan Menteri Keuangan Republik Indonesia Nomor 113/PMK.03/2014.

Tabel 1 : Harga Rumah Sederhana Murah berdasarkan Surat Keputusan Menteri PUPR

\begin{tabular}{cccc}
\hline Tahun & $\begin{array}{c}\text { Harga RSM } \\
\text { (Juta Rupiah) }\end{array}$ & $\begin{array}{c}\text { Kenaikan } \\
\text { (Juta Rupiah) }\end{array}$ & $\begin{array}{c}\text { Penghasilan } \\
\text { maksimal } \\
\text { (Juta Rupiah) }\end{array}$ \\
\hline 2020 & 164,50 & - & 5,00 \\
2019 & 153,00 & 11,50 & 4,00 \\
2018 & 142,00 & 11,00 & 4,00 \\
2017 & 135,00 & 7,00 & 4,00 \\
2016 & 128,00 & 7,00 & 4,00 \\
2015 & 121,00 & 7,00 & 4,00 \\
2014 & 115,00 & 6,00 & 4,00 \\
\hline
\end{tabular}

Pada Table 1 dapat dilihat bahwa harga jual rumah sederhana murah mengalami kenaikan pada setiap tahunnya, kenaikan harga tersebut dapat dilihat pada kolom kenaikan. Sementara pada kolom penghasilan maksimal memuat nilai penghasilan atau gaji maksimal dari MBR yang boleh memanfaatkan fasilitas kredit pemilikan rumah FLPP. Nilai-nilai yang tertera dalam table 1 berasal dari Surat Keputusan Menteri PUPR.

Gambar 2 adalah grafik yang menunjukan kurva kenaikan harga rumah sederhana murah yang setiap tahunnya mengalami kenaikan harga.

Namun sangat disayangkan, sekalipun harga jual rumah sederhana murah telah diatur dalam Surat Keputusan Menteri PUPR, masih ada pengembang perumahan yang menjual rumah sederhana murah kepada MBR dengan harga diatas harga maksimal yang telah ditetapkan. Pengembang perumahan yang menjual rumah sederhana murah dengan harga diatas harga maksimal, umumnya tetap mengajukan kredit pemilikan rumah FLPP dengan pokok kredit sesuai ketentuan, namun selain uang muka $1 \%$ yang harus dibayarkan oleh MBR, maka MBR tersebut masih diwajibkan membayar selisih antara harga jual dengan pokok kredit setelah dikurangi $1 \%$ yang dihitung juga sebagai uang muka. Dengan kata lain dapat dikatakan bahwa uang muka dari harga rumah sederhana murah tersebut lebih dari 1\%. Yang sampai saat ini masih berlaku dan belum tersentuh sangsi hukum.

\section{Biaya Kontruksi Rumah}

Yang dimaksud dengan biaya kontruksi Rumah di sini adalah biaya yang dianggarkan untuk membangun 1 unit rumah. Yang mana rumah tersebut merupakan rumah sederhana murah tipe 36 .

Yang besar biaya kontruksi rumahnya merupakan turunan dari harga jual rumah sederhana murah setelah dikurangi dengan biaya perijinan, biaya lahan dan biaya PSU. Harga jual rumah sederhana murah tersebut sesuai dengan harga jual maksimum yang ditetapkan dalam Surat Keputusan Menterian PUPR tahun 2018.

Selanjutnya untuk mengetahui biaya kontruksi rumah sederhana murah, maka perlu dilakukan analisis perbandingan terhadap beberapa perumahan yang membangun perumahan rumah sederhana murah bagi MBR. Di sini, diambil empat sampel perumahan. Perbandingan dilakukan terhadap harga jual dan RAB perumahan dari ke-4 sampel tersebut. Ke 4 sampel perumahan tersebut menjual rumah sederhana murah pada harga yang sama dan mengikuti harga jual maksimal yang ditetapkan pemerintah.

Tabel 2 Prosentase biaya perumahan RSM

\begin{tabular}{ccc|c|c}
\hline \multirow{2}{*}{ Sampel } & \multicolumn{4}{c}{ Biaya (Prosentase) } \\
& Perijinan & Lahan & PSU & Rumah \\
\hline Perum. A & $5 \%$ & $30 \%$ & $15 \%$ & $50 \%$ \\
Perum. B & $7 \%$ & $30 \%$ & $16 \%$ & $47 \%$ \\
Perum. C & $7 \%$ & $32 \%$ & $17 \%$ & $44 \%$ \\
Perum. D & $6 \%$ & $35 \%$ & $20 \%$ & $39 \%$ \\
\hline Rata-rata & $6 \%$ & $32 \%$ & $17 \%$ & $45 \%$ \\
\hline
\end{tabular}

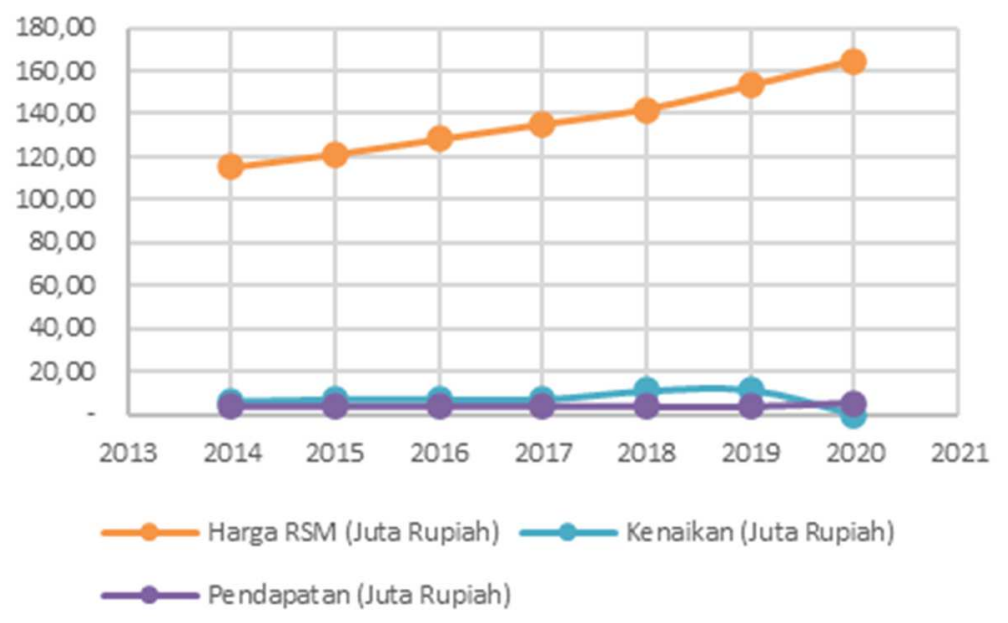

Gambar 2 : Grafik Harga Rumah Sederhana Murah 


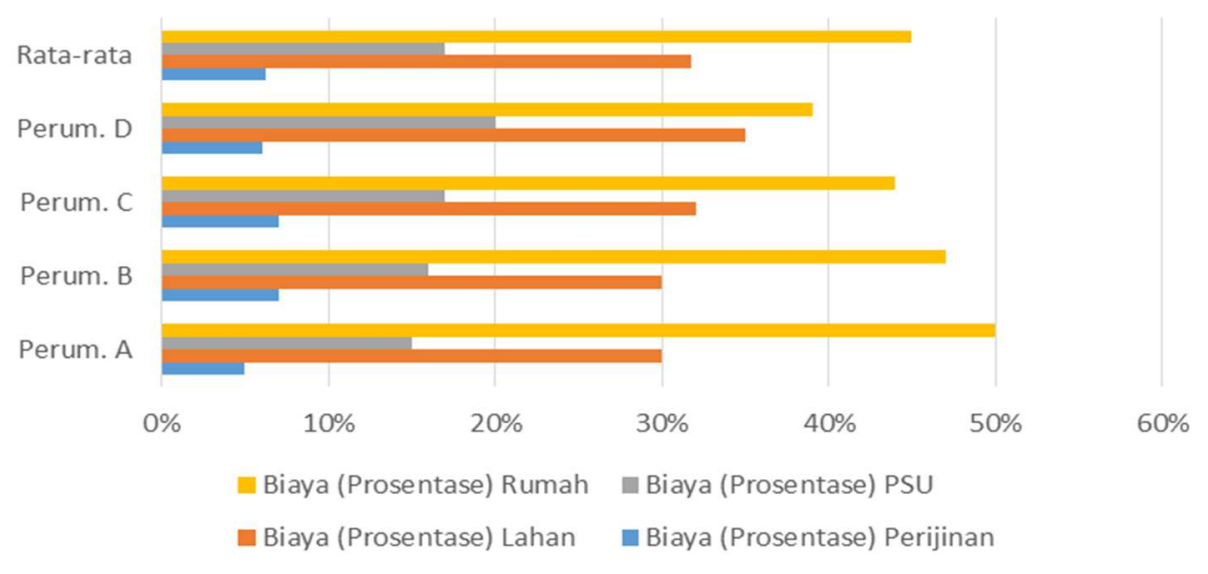

Gambar 3 : Grafis biaya perumahan RSM

Biaya hanya ditampilkan prosentase biaya perijinan, biaya lahan, biaya PSU dan Biaya kotruksi RSM. Untuk biaya tidak langsung diabaikan, karena tidak termasuk dalam komponen biaya pada RAB perumahan.

Biaya hanya ditampilkan prosentase biaya perijinan, biaya lahan, biaya PSU dan Biaya kotruksi RSM. Untuk biaya tidak langsung diabaikan, karena tidak termasuk dalam komponen biaya pada RAB perumahan.

Dari Tabel 2 dan Gambar 3 dapat dilihat dan diketahui bahwa terdapat perbedaan biaya antara ke 4 sampel perumahan tersebut terhadap biaya perijinan, biaya lahan, biaya PSU dan biaya kontruksi RSM. Namun perbedaan biaya tersebut tidaklah signifikan dan masih dalam batas toleransi dalam suatu proyek perumahan. Sehingga dihitung biaya atau nilai rata-rata dari ke 4 sampel perumahan tersebut, yang kemudian dihitung dan dihadirkan dalam prosentase biaya.

Jika dikaitkan dengan harga jual rumah sederhana murah di tahun 2018, maka biaya kontruksi 1 unit rumah sederhana murah adalah prosentasi biaya kontruksi RSM dikalikan dengan harga jual maksimal rumah sederhana murah, yakni; 45\% dikalikan 142 juta rupiah, sehingga diperoleh nominal biaya kontruksi RSM 63,9 juta rupiah.

\section{Pemilihan Kontruksi Rumah Sederhana Murah}

Rancangan kontruksi rumah sederhana murah baik model, denah, struktur maupun material harus dibuat berdasarkan biaya kontruksi RSM yang telah dihitung dari harga jual rumah sederhana murah, yaitu sebesar 63,9 juta rupiah. Selanjutnya akan disebut alokasi biaya kontruksi RSM.

Untuk kebutuhan analisis, maka dibuat simulasi yaitu dengan melakukan perbandingan 4 sampel rumah sederhana murah. Yang mana luas bangunan, tipe, model dan denah ke 4 sampel tersebut adalah sama.

Sampel ke-1 adalah rumah sederhana murah tipe 36 , luas bangunan 36 meter persegi, pondasi pasangan batako 1 bata, struktur kayu ulin, dinding pasangan batako diplester dan diaci, atap seng gelombang, plafon triplek dan lantai pasangan keramik.
Sampel ke-2 adalah rumah sederhana murah tipe 36, luas bangunan 36 meter persegi, pondasi pasangan batako 1 bata, struktur kayu ulin, dinding pasangan batako tidak diplester, atap seng gelombang, tanpa plafon dan lantai rabat beton diaci.

Rancangan kontruksi untuk sampel ke-3 adalah rumah sederhana murah tipe 36, luas bangunan 36 meter persegi, pondasi pasangan batako 1 bata, struktur besi UNP5 dan dibeton, kuda-kuda besi UNP5, dinding pasangan batako tidak diplester, atap seng gelombang, tanpa plafon dan lantai rabat beton diaci.

Tabel 3 Sampel Biaya Kontruksi RSM

\begin{tabular}{lcccc}
\hline URAIAN & $\begin{array}{c}\text { Sampel } \\
\text { ke-1 }\end{array}$ & $\begin{array}{c}\text { Sampel } \\
\text { ke-2 }\end{array}$ & $\begin{array}{c}\text { Sampel } \\
\text { ke-3 }\end{array}$ & $\begin{array}{c}\text { Sampel } \\
\text { ke-4 }\end{array}$ \\
\hline $\begin{array}{l}\text { Alokasi Biaya } \\
\text { Kontruksi }\end{array}$ & 63.900 .000 & 63.900 .000 & 63.900 .000 & 63.900 .000 \\
$\begin{array}{l}\text { RSM } \\
\text { Biaya } \\
\text { Kontruksi }\end{array}$ & 87.668 .000 & 63.500 .000 & 58.757 .000 & 45.736 .000 \\
RSM & & & & \\
$\begin{array}{l}\text { Selisih Biaya } \\
\text { Kontruksi }\end{array}$ & 23.768 .000 & 400.000 & 5.143 .000 & 18.164 .000 \\
\hline
\end{tabular}

Tabel 4 Sampel Biaya Kontruksi RSM

\begin{tabular}{lcccc}
\hline URAIAN & $\begin{array}{c}\text { Sampel } \\
\text { ke-1 }\end{array}$ & $\begin{array}{c}\text { Sampel } \\
\text { ke-2 }\end{array}$ & $\begin{array}{c}\text { Sampel } \\
\text { ke-3 }\end{array}$ & $\begin{array}{c}\text { Sampel } \\
\text { ke-4 }\end{array}$ \\
\hline $\begin{array}{l}\text { Alokasi B.Ijin, } \\
\text { Ihn \& PSU } \\
\text { Biaya } \\
\text { Kontruksi }\end{array}$ & 78.100 .000 & 78.100 .000 & 78.100 .000 & 78.100 .000 \\
$\begin{array}{l}\text { RSM } \\
\text { Harga Jual }\end{array}$ & 87.668 .000 & 63.500 .000 & 58.757 .000 & 45.736 .000 \\
$\begin{array}{l}\text { Rumah } \\
\text { (Sampel) }\end{array}$ & 165.768 .000 & 141.600 .000 & 136.857 .000 & 123.836 .000 \\
$\begin{array}{l}\text { Harga Jual } \\
\text { Rumah (SK } \\
\text { Menteri) }\end{array}$ & 142.000 .000 & 142.000 .000 & 142.000 .000 & 142.000 .000 \\
\begin{tabular}{l} 
Selisih Harga \\
\hline
\end{tabular} & -23.768 .000 & 400.000 & 5.143 .000 & 18.164 .000 \\
\hline
\end{tabular}

Dan rancangan untuk sampel ke-4 adalah rumah sederhana murah tipe 36, luas bangunan 36 meter persegi, pondasi pasangan batako 1 bata, slof beton praktis, struktur dan kuda-kuda bajaringan C75.100, rangka dinding bajaringan $C 75.75$, dinding fiber semen 
$6 \mathrm{~mm}$ dan $8 \mathrm{~mm}$, rangka atap bajaringan, atap seng gelombang, tanpa plafon dan lantai rabat beton diaci.

Kemudian RAB seluruh sampel tersebut dihitung berdasarkan AHSP Kota Balikpapan Tahun 2018 agar dapat diketahui biaya kontruksi RSM dari empat sampel tersebut.

Pada Tabel 3 diketahui bahwa alokasi biaya kontruksi RSM adalah sebesar 63,9 juta rupiah dan besar biaya kontruksi RSM dari ke 4 sampel itu diperoleh dari RAB masing-masing sampel tersebut. Jika dihitung selisihnya, maka untuk sampel ke-1 menunjukan bahwa biaya kontruksi RSHnya melebihi alokasi biaya kontruksi RSM yang ditentukan. Sementara untuk sampel ke2, sampel ke-3 dan sampel ke-4 menunjukan bahwa biaya kontruksi RSMnya tidak melebihi alokasi biaya kontruksi RSM yang ditentukan.

Dari Tabel 4 dapat diketahui bahwa perubahan biaya kontruksi RSM secara keseluruhan mempengaruhi harga jual RSM. Dengan kata lain bahwa pemilihan kontruksi rumah sederhana murah yang digunakan sangat mempengaruhi biaya kontruksi RSM dan harga jual RSM.

\section{Penghasilan Maksimal}

Yang dimaksud dengan Penghasilan maksimal atau penghasilan perbulan paling banyak oleh Surat Keputusan Menteri PUPR adalah Batasan penghasilan kelompok sasaran yang dapat memanfaatkan KPR subsidi, yang dihitung berdasarkan penghasilan tetap berupa gaji atau upah pokok perbulan dan/atau penghasilan tidak tetap berupa pendapatan bersih atau upah rata-rata perbulan dalam setahun yang diterima.

Kelompok sasaran yang dimaksud di atas adalah MBR dan KPR Subsidi adalah Kredit Pemilikan Rumah FLPP.

Penghasilan tetap MBR dapat dibuktikan melalui slip gaji atau upah perbulan yang diperhitungkan dari gaji atau upah pokok dalam kurun waktu 3 bulan berturutturut.

Penghasilan tidak tetap dapat dibuktikan dengan kwitansi atau bukti pembayaran upah harian atau bulanan yang diperhitungkan dari upah rata-rata perbulan dalam setahun. Atau bagi wirausaha dapat membuktikan penghasilannya melalui surat penyataan atau surat keterangan penghasilan berupa laporan pendapatan, laporan rugi laba dan laporan neraca serta rekening koran yang ditandatangani oleh pihak bank minimal 3 bulan berturut-turut.

Penghasilan maksimal yang perbolehkan untuk memanfaatkan kredit pemilikan rumah FLPP adalah sebesar 4 juta rupiah seperti yang tercantum dalam Tabel 1 sebagaimana Surat Keputusan Menteri PUPR Nomor 1126/KPTS/M/2018.

Namun lagi-lagi sangat disayangkan yang pada kenyataannya bahwa kelompok sasaran MBR yang berpenghasilan tidak tetap masih banyak yang tidak dapat memanfaatkan fasilitas kredit pemilikan rumah FLPP, karena ditolak oleh Bank Pelaksana dengan berbagai alasan. Adapun MBR yang berpenghasilan tidak tetap yang dapat memanfaatkan fasilitas tersebut, namun jumlahnya tidak seberapa, jika dibandingkan dengan jumlah MBR berpenghasilan tidak tetap yang membutuhkan fasilitas tersebut.

\section{Kemampuan Membayar Angsuran}

Kemampuan membayar angsuran yang dimaksud di sini adalah kemampuan seorang MBR sebagai calon debitur yang akan memanfaatkan Kredit Pemilikan Rumah FLPP pada Bank Pelaksana yang ditunjuk oleh pemerintah dalam membayar angsuran bulanan.

Kemampuan membayar angsuran seorang MBR dapat diukur dengan cara mengalikan nilai koefisien dengan penghasilan atau gaji atau upah pokok yang diperoleh MBR tersebut. Nilai dari koefisien tersebut adalah $1 / 3$.

Tabel 5 Kemampuan MBR Dalam Membayar Angsuran (Penghasilan dikali satu pertiga)

\begin{tabular}{|c|c|c|c|}
\hline Kelas & Penghasilan & KMA & Keterangan \\
\hline 1 & 1.500 .000 & 500.000 & \multirow{6}{*}{$\begin{array}{l}\text { - Nominal da la m rupiah } \\
\text { - Penghasilan = penghasilan } \\
\text { dari gaji atau upah } \\
\text { - KMA= Kemampuan } \\
\text { Membayar Angsuran }\end{array}$} \\
\hline 2 & 1.999 .999 & 666.666 & \\
\hline 3 & 2.000 .000 & 666.667 & \\
\hline 4 & 2.999 .999 & 1.000 .000 & \\
\hline 5 & 3.000 .000 & 1.000 .000 & \\
\hline 6 & 4.000 .000 & 1.333 .333 & \\
\hline
\end{tabular}

Berdasarkan data penggajian ASN, TNI dan Polri yang ditetapkan oleh Peraturan Pemerintah dan Upah Minimum Provinsi dan Kota/Kabupaten yang ditetapkan oleh Pemerintah Daerah, maka dibagi penghasilan MBR ke dalam enam kelas. Adapun kelas penghasilan dari MBR tersebut dapat dilihat pada Tabel 5.

\section{Daya Beli MBR}

Daya beli MBR adalah kemampuan seorang MBR dalam melakukan pembelian rumah sederhana murah melalui fasilitas Kredit Pemilikan Rumah FLPP yang disediakan oleh pemerintah melalui Bank Pelaksana.

Kemampuan yang dimaksud adalah mampu dalam menyediakan biaya akat kredit, mampu membayar uang muka sebesar $1 \%$ dan mampu membayar angsuran bulanan.

Selanjutnya diasumsi bahwa MBR sanggup dalam menyediakan uang muka dan biaya akat kredit, sehingga yang jadi dasar analisis daya beli MBR dititikberatkan pada kemampuan MBR dalam membayar angsuran.

Pada Gambar 4 ditampilkan grafik daya beli MBR yang membandingkan antara penghasilan MBR dengan kemampuan MBR dalam membayar angsuran. Dalam grafik tersebut jelas terlihat bahwa MBR yang memiliki penghasilan antara 2,9 juta hingga 4 juta rupiah adalah MBR yang memiliki kemampuan membayar angsuran bulanan. Sementara untuk MBR yang berpenghasilan kurang dari 2,9 juta rupiah dapat dikatakan tidak 


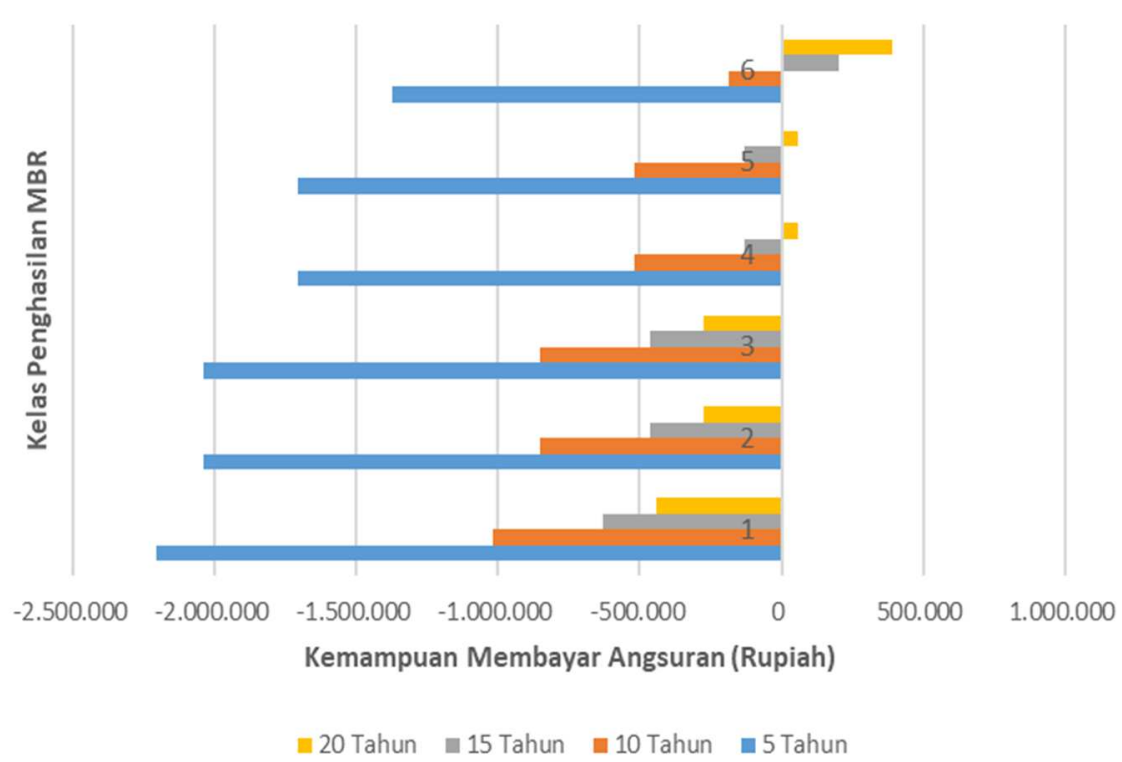

Gambar 4 Daya Beli MBR

memiliki kemampuan membayar angsuran bulanan atau dengan kata lain tidak memiliki daya beli.

Dari hasil analisis diketahui bahwa MBR yang berpenghasilan antara 2,9 juta hingga 3,4 juta rupiah memiliki kemampuan membayar angsuran bulanan atau memiliki daya beli, jika jangka waktu kredit pemilikan rumah yang dimohonkan adalah 20 tahun. Sementara MBR yang berpenghasilan 3,5 juta hingga 4 juta rupiah memiliki kemampuan membayar angsuran bulanan atau memiliki daya beli, jika jangka waktu kredit yang dimohonkan minimum 15 tahun.

\section{Analisis}

Selanjutnya digunakan data pada Gambar 4 dan data pada Tabel 4 dan Tabel 5 sebagai dasar dan pedoman dalam membuat analisis grafik. Yang mana input data menggunakan daya beli MBR pada jangka waktu angsuran 15 tahun. Sementara biaya kontruksi RSH menggunakan data harga jual RSM menurut Surat Keputusan Menteri PUPR, harga jual Sampel I, harga jual Sampel II, harga jual Sampel III dan harga jual Sampel IV.

Dari Gambar 5 terbaca dengan jelas bahwa daya beli MBR semakin meningkat seiring dengan berkurangnya biaya kontruksi rumah sederhana murah. Sebagaimana ditunjukan pada kurva MBR kelas 6 dan pada kurva MBR kelas 5 .

Untuk lebih detailnya, maka dapat membaca prosentase pada grafik tersebut. Yang mana nilai prosentase tersebut menunjukan tingkat daya beli MBR. Jika nilai prosentase menunjukan nilai yang kurang dari $1,00 \%$ itu berarti MBR tersebut tidak memiliki daya beli dan jika nilai prosentase menunjukan nilai yang sama dengan dan/atau lebih dari $1,00 \%$ itu berarti MBR tersebut memiliki daya beli. Peningkatan nilai prosesntasi lebih dari 1,00\% menunjukan bahwa kemampuan daya beli MBR semakin meningkat.

\section{Kesimpulan}

Dari hasil analisis grafik, maka dapat disimpulkan beberapa hal-hal berikut ini :

1. Semakin kecil biaya kontruksi rumah, maka semakin meningkat daya beli MBR dan/atau sebaliknya.

2. Perubahan pada kontruksi rumah secara langsung akan mempengaruhi biaya kontruksi rumah, harga jual rumah dan daya beli MBR.

3. Harga jual rumah maksimal yang ditetapkan oleh Surat Keputusan Menteri PUPR pada tahun 2018 hanya mengakomodir MBR yang berpenghasilan 2,9 juta hingga 4 juta dengan jangka kredit minimal 15 tahun.

4. Dari hasil analisis di atas, bisa dikatakan bahwa daya beli MBR sangat rendah terhadap terhadap harga jual rumah atau biaya kontruksi rumah.

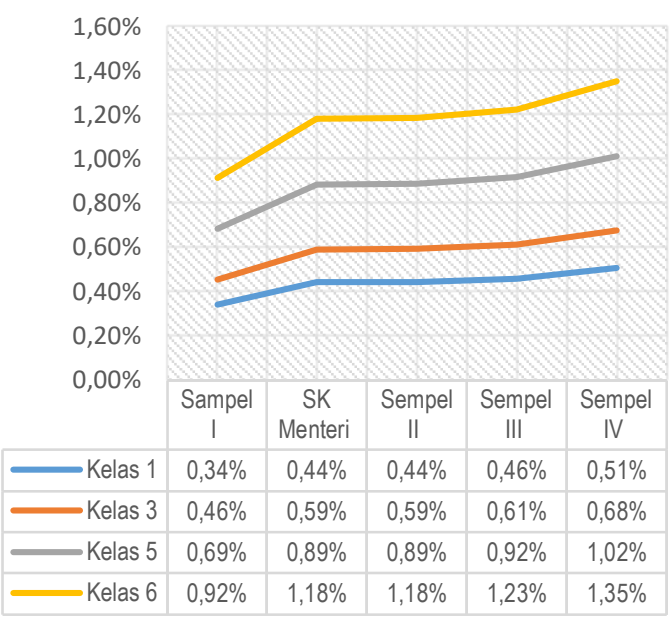

Gambar 5 Grafik Perbandingan Antara Daya Beli MBR dengan Biaya Kontruksi Rumah 
5. Untuk itu diperlukan komitmen bersama bagi insinyur teknik sipil dalam merancangan dan merekayasa kontruksi rumah sederhana murah sehingga dapat menciptakan kontruksi rumah yang benar-benar murah dan terjangkau oleh MBR.

6. Jika dapat diciptakan kontruksi rumah sederhana murah yang benar-benar murah dan terjangkau, maka secara langsung akan meningkatkan daya beli MBR.

\section{Referensi}

Dinas PU Kota Balikpapan (2018) Analisa Harga Satuan Pekerjaan Kota Balikpapan Tahun 2018. Balikpapan: Dinas PU Kota Balikpapan.

Keputusan Menteri PUPR Nomor 425/KPTS/M/2015. (2015) Jakarta: Biro Hukum Menteri PUPR.

Keputusan Menteri PUPR Nomor 552/KPTS/M/2016. (2016) Jakarta: Biro Hukum Menteri PUPR.
Keputusan Menteri PUPR Nomor 1126/KPTS/M/2018. (2018) Jakarta: Biro Hukum Menteri PUPR.

Keputusan Menteri PUPR Nomor 535/KPTS/M/2019. (2019) Jakarta: Biro Hukum Menteri PUPR.

Keputusan Menteri PUPR Nomor 242/KPTS/M/2020. (2020) Jakarta: Biro Hukum Menteri PUPR.

Nabila, M (2019) Kurangi Backlog, PUPR Utamakan Program Rumah Komunitas. Jakarta: Bisnis.com

Peraturan Menteri Keuangan RI Nomor 113/PMK.03/ 2014. 2014. Jakarta: Biro Hukum Menteri PUPR.

Surat Keputusan Gubernur Kaltim (2019) Penetapan UMP dan UMK. Samarinda: Sekertariatan Kantor Gubernur.

Triasari, D. (2019) Undang Undang Dasar 1945 dan Amandemen Super Komplet. Sleman-Yogyakarta: Charissa Publisher.

Undang Undang Republik Indonesia Nomor 1 Tahun 2011 Tentang Perumahan dan Kawasan Permukiman. (2012) Jakarta: Biro Hukum dan Kepegawaian Kementerian Perumahan Rakyat. 